\title{
HORMONAL MECHANISMS IN ESSENTIAL HYPERTENSION
}

\author{
Mariana Dobrescuํ. Diana Păun², Sorina Buculei ${ }^{1}$, Daniel Grigorie², Cătălina Poiană² \\ ${ }^{1}$ SANADOR Medical Center, Bucharest \\ 2 "Carol Davila" University of Medicine and Pharmacy, Bucharest
}

\begin{abstract}
"Essential" hypertension is related to multiple mechanisms that affect cardiac output and peripheral resistance and is a consequence of the interaction between external factors and genetic factors. Neuro-hormonal factors are essential in the pathophysiology of hypertension and among them the renin-angiotensin-aldosterone system (RAAS) has a main role in the physiological and pathological response of the cardiovascular system.

RAAS functions as an endocrine system, but also has paracrine and autocrine functions in many tissues and organs. RAAS regulates extracellular fluid volume and peripheral resistance via systemic and local actions in various tissues. RAAS also participates in endothelial dysfunction, inflammation and vascular fibrosis, cardiac fibrosis and cardiovascular remodelling, with worsening hypertension and target organ injury. Aldosterone is involved in "essential" hypertension via discrete variations in the regulation of aldosterone synthesis in the absence of confirmed primary hyperaldosteronism. A complete evaluation of these systems is needed for a thorough understanding of hypertension.
\end{abstract}

Keywords: essential hypertension, endothelial dysfunction, salt intake, genetic mechanisms.

\section{Rezumat}

HTA „esenţială” este legată de multiple mecanisme care afectează debitul cardiac şi rezistenţa periferică şi este o consecinţă a interacţiunii dintre factorii externi şi factorii genetici. Factorii neuro-hormonali sunt esenţiali în fiziopatologia HTA şi dintre aceştia sistemul reninăangiotensină-aldosteron (RAAS) are un rol central în răspunsul fiziologic şi patologic al sistemului cardiovascular.

RAAS funcţionează ca un sistem endocrin, dar are şi funcţii paracrine şi autocrine în numeroase ţesuturi şi organe. RAAS reglează volumul lichidului extracelular şi rezistenţa periferică prin acţiuni sistemice şi locale în diferite ţesuturi. De asemenea, RAAS participă la disfuncţia endotelială, inflamaţia şi fibroza vasculară, fibroza cardiacă şi remodelarea cardiovasculară, cu agravarea hipertensiunii şi injurie în organele ţintă. Aldosteronul este implicat în HTA „esenţială" prin intermediul variaţiilor discrete în reglarea sintezei de aldosteron, în absenţa hiperaldosteronismului primar confirmat. Evaluarea completă a acestor sisteme este necesară pentru înţelegerea aprofundată a HTA.

Cuvinte cheie: hipertensiunea esenţială, disfuncţia endotelială, consumul de sare, mecanisme genetice. 


\section{INTERNAI}

\section{General Reviews}

"Essential" hypertension has been classically estimated in $95-99 \%$ of cases of hypertension and is considered to have no known cause. This postulate has been refuted mainly by genetic studies on the causes of increased $B P$, which have outlined a certain neurohormonal spectrum associated with hypertension, in genetically susceptible individuals. Currently, multiple factors that sum up their effects are being studied: genetic factors, sympathetic NS hyperactivity, renal mechanisms, excess salt ingestion and pressure natriuresis, vascular mechanisms (endothelial cell dysfunction and nitric oxide pathway), hormonal mechanisms (renin-angiotensin-aldosterone system - RAAS), obesity, sedentary lifestyle, aging, stress, obstructive sleep apnoea (OSA), insulin resistance and metabolic syndrome, vitamin $D$, low calcium level, low potassium level, racial, ethnic, gender and environmental factors.

Sympathetic hyperactivity has the maximum involvement in the pathophysiology of hypertension, either directly or indirectly via multiple mechanisms that include RAAS, OSA, obesity.

The autonomic nervous system is especially involved in the dysregulation of the basal sympathetic tone via the hypothalamus or even with cortical influences. Prolonged sympathetic hyperactivity and secondary vasoconstriction induce vascular hypertrophy with progressive increase in peripheral resistance and BP.

Endothelial dysfunction in hypertension is favoured by oxidative stress, with a dysregulation of the balance between vasodilatory factors (nitric oxide) and vasoconstrictive factors (reactive oxygen species - ROS). This results in increased vascular tone, cell proliferation and activation of adhesion molecules in the endothelium, dysregulation of the coagulation/fibrinolysis balance and finally atherosclerotic disease with target organ injury. Hormonal mechanisms (especially ANG II) actively participate in this process $^{(1,2,3,4)}$.

Hypothesis on sodium/potassium ratio in essential hypertension: classically, excessive sodium intake was thought to contribute to an increased risk of hypertension, and potassium was considered a minor factor in the pathogenesis of hypertension. Many current data indicate that potassium deficiency plays an important role in causing hypertension, and the imbalance between $\mathrm{Na}$ and $\mathrm{K}$ levels favours vascular smooth muscle contraction, reduced blood flow and increased BP.

The contribution of RAS and adrenal steroids in the development of hypertension is particularly complex. RAAS functions as an endocrine system, but also has paracrine and autocrine functions in many tissues and 
organs. Classically, the RAAS has been shown to be an endocrine system involved in the regulation of blood pressure and electrolytes, but has subsequently been shown to be also involved in inflammation, endothelial dysfunction, atherosclerosis, hypertension, heart failure. Disorders of the system play an important role in the pathophysiology of hypertension, kidney diseases and congestive heart failure. Moreover, in the course of long-standing hypertension, target organ aggression is a consequence of high blood pressure, but also of hormonal factors such as aldosterone and ANG $\|^{(1)}$.

Renin is a circulating enzyme that participates in the regulation of BP by maintaining extracellular volume and arterial vasoconstriction. Angiotensin II (ANG II) is the primary effector hormone of the RAS that influences the function of all organs, including the heart, kidneys, vessels, brain, with favourable or unfavourable effects. In addition to ANG II, the primary effector hormone of RAS, the biological activity of ACE2 and degradation products of ANG II (ANG-1-7, ANG III, ANG IV) was studied. ANG II plays a main role in initiating and amplifying the pathophysiological mechanisms that lead to vascular disease. ANG II is a potent vasoconstrictor, which increases peripheral resistance and $\mathrm{BP}$ and stimulates aldosterone secretion; the increase in $\mathrm{BP}$ is produced by decreased vasodilatory factors (NO) and increased vasoconstrictive factors (ROS and oxidative stress).

The actions of ANG II are the result of binding to specific AT1 and AT2 receptors belonging to the large family of G-protein receptors. The effects of the two types of receptors are completely different and their signals in apparent opposition (e.g. AT1 mediates vasoconstrictor effects while AT2 mediates vasodilator effects) $)^{(5,6,7,8,9)}$.
Local production of ANG II in various tissues (vascular system, heart, adrenal glands, brain, adipose tissue, placenta, kidneys) is controlled by ACE and other enzymes. Interaction of ANG II with AT1 receptors triggers an increased aldosterone secretion, renin suppression, modulation of renal sodium resorption, increased vasopressin secretion, altered cardiac function and changes in immune response. Locally produced ANG II acts as a biologically active mediator and participates in cardiovascular injury via direct effects on endothelial cells and vascular smooth muscle cells with vasoconstriction, endothelial dysfunction, pro-inflammatory phenotype, pro-thrombotic phenotype, remodelling.

Via these mechanisms, the local renin-ANG II system contributes to increased vascular resistance, vascular remodelling in hypertension and unfavourable evolution with target organ damage. The circulating level of ANG II is either the result of the action of renin secreted in the kidney or comes from intrarenal synthesis. The intrarenal reninangiotensin II system (RAS) plays a very important role, with significant concentrations of renin and ANG II detected in the tubular system and renal interstitial fluid resulting from continuous local formation in the kidney $(85 \%$ of ANG II present in renal tissue comes from local production, the rest may be further increased by uptake from the peripheral circulation).

However, low peripheral ANG II levels can cause BP to increase and be maintained. Thus, in forms of hypertension with low plasma renin activity (PRA), ANG II contributes to the maintenance of hypertension, although circulating ANG II levels are not different from normotensives ${ }^{(10,11)}$.

RAAS is activated by many factors: excess salt, obesity, sedentary lifestyle, insulin 


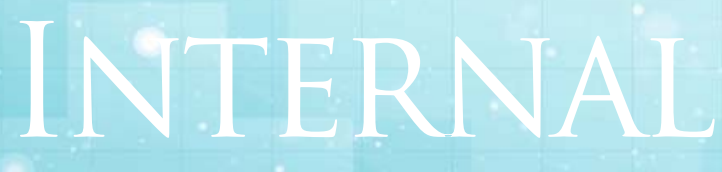

General Reviews

resistance, increased alcohol consumption, low potassium levels, and many of these factors add up. Obesity and excessive salt intake are essential factors that stimulate RAAS and the pathological effects of ANG II. Obesity and hypertension are closely associated, with an estimated $65-78 \%$ of hypertension cases attributable to obesity. The prevalence of hypertension increases progressively with increasing BMI, from 15\% in those with $\mathrm{BMI}<25 \mathrm{~kg} / \mathrm{m}^{2}$ to $40 \%$ for people with BMI of $30 \mathrm{~kg} / \mathrm{m}^{2}$ or above. Obesityrelated hypertension is the result of the complex interaction of numerous pathophysiological mechanisms among which increased vascular reactivity, oxidative stress, endothelial dysfunction and vascular remodelling may be causes or consequences of increased BP. At the same time, adipose tissue interrelates with the sympathetic NS and RAAS; via this pathway, adipose tissue interacts with pro-inflammatory mechanisms, vascular structures and modulates cardiovascular injury. The relationship between hypertension and obesity is mediated by RAAS and insulin resistance. Tissular RAAS in adipose tissue may play an important role in adipose tissue function, and adipocytes have the ability to synthesize all RAAS components. In humans, BMI correlates with plasma ANG II levels, plasma renin activity (PRA) and plasma ACE. Correlations have been cited between ANG II- leptin and PRA-leptin, and weight loss is associated with decreases in PRA, aldosterone and BP. In addition, genetic mutations of RAAS associated with obesity and hypertension are being studied. (Overexpression of genes for renin, ACE and AT1 receptors has been demonstrated in obese hypertensive women $)^{(12,13,14,15,16,17)}$. On the other hand, ANG II action is related to salt intake. The pressor response to ANG II is closely related to salt intake, and the kidney monitors the relationship between salt intake, renin secretion, ANG II and fluid volume. In both essential and renovascular hypertension circulating ANG II levels may be inadequate compared to salt intake.

Under physiological conditions, ANG II is of indisputable importance in the cardiovascular system and participates minute by minute in the regulation of spatial adaptation. After binding to AT1 receptors, it rapidly (seconds, minutes) activates mechanisms that produce VSMC (vascular smooth muscle cell) contraction, with maintenance of vascular tone. Under conditions of dysregulation of the RAS balance (by genetic or environmental factors) the pathological effects of ANG II occur. Prolonged exposure to ANG II usually results in its cytokine-like effects, which promote cell growth and migration, extracellular matrix deposition, with vascular and cardiac remodelling ${ }^{(1,2,18,19)}$. 
- ANG II induces imbalances between vasodilatory factors (NO) and vasoconstrictive agents (ROS) and thus promotes vasoconstriction, proinflammatory and pro-thrombotic effects.

- ANG II induces endothelial dysfunction and activates the pro-inflammatory phenotype in VSMCs

- ANG II is involved in vascular remodelling

- ANG II unbalances the balance between the fibrinolytic and coagulation systems (stimulates PAI-1 synthesis and reduces tPA production) with the development of a prothrombotic status.

Aldosterone, another major component of the RAAS, is involved in BP mechanisms under both physiological and pathological conditions: it contributes to the maintenance of blood pressure in the normal population, and increased aldosterone secretion contributes to increased risk of hypertension in the general population. Aldosterone stimulates increased salt and water reabsorption in the kidney with increased blood volume, BP and vascular injury with fibrosis and decreased vascular compliance $^{(20,21,22)}$.

Longitudinal studies of blood pressure, renin and aldosterone suggest that aldosterone secretion is under genetic control and by this way it may have modest but long-lasting increases during lifetime. Large population studies have shown that both aldosterone levels and blood pressure increase with age, and variable aldosterone levels within normal limits may predict the increase in blood pressure with age. An example is the onset of high-volume hypertension in the elderly which is thought to be a consequence of the relative excess of aldosterone in early life. In these cases genetically determined increases in aldosterone secretion could lead during lifetime after many years to increased vulume and low renine hypertension with increased aldosterone/renine ratio ${ }^{(23,24)}$. In the course of long-standing hypertension, target organ aggression is a consequence of high blood pressure, but also of hormonal factors such as aldosterone and ANG II. Multiple studies show that aldosterone causes vascular injury with fibrosis and decreased vascular compliance.

\section{Classic forms of essential hypertension}

The classical classification of hypertension based on plasma renin activity (PRA) levels is useful for a good understanding of pathophysiological mechanisms:

- Low renin hypertension (Iow PRA) is considered volume-dependent and has distinct pathophysiological characteristics that include sensitivity to salt, response to diuretics and favourable natural history. Plasma renin activity is low, does not respond normally to $\mathrm{Na}$ restriction and maintains basal aldosterone levels; aldosterone although not elevated, is inadequate to the level of its stimulus, ANG II. This form of hypertension is favoured by genetic factors, old age, race and diabetes ${ }^{(25,26)}$.

- Normal or high PRA ("non-modulating") hypertension is considered vasoconstrictor-dependent, saltsensitive, prone to $\mathrm{Na}$ retention in both acute and chronic conditions, and is associated with features that distinguish it from low renin hypertension:

$\rightarrow$ insulin resistance

$\rightarrow$ hypercholesterolemia 


\section{INTERNAI}

\section{General Reviews}

$\rightarrow$ family history of hypertension and ischemic heart disease

$\rightarrow$ decreased adrenal response to ANG II evidenced by restriction of $\mathrm{Na}$ intake. Increased salt intake fails to alter the adrenal and vascular response to ANG II (Na ingestion does not produce the reciprocal adrenal - aldosterone response, and ANG II infusion does not induce the usual renal vascular effect). The fundamental mechanism of nonmodulating hypertension is related to changes in renal and adrenal RAAS suggesting inadequate local excess of ANG II in the kidney.

These abnormalities are corrected by ACE inhibitors (ACE-I) and ANG II receptor blockers (ARBS), and hypertension responds better to these drugs than to diuretics. The genetic basis of non-modulating hypertension is now demonstrated and is supported by multiple studies ${ }^{(27,28,29,30)}$ :

$\rightarrow$ significant family incidence: non-modulating hypertensives have frequently family history (up to $80 \%$ of cases)

$\rightarrow$ non-modulating traits are also present in normotensive individuals

$\rightarrow$ association of the non-modulating phenotype with the 235T angiotensinogen gene polymorphism

$\rightarrow$ association with ACE and aldosterone synthase gene polymorphism.
- The classification of patients with hypertension into "modulating" and "nonmodulating" was made in relation to the renal haemodynamic response to salt intake and ANG II:

$\rightarrow$ The "modulating" group of patients responds to saline infusion with exaggerated natriuresis, and administration of ACE inhibitors does not influence the renal haemodynamic response;

$\rightarrow$ The "non-modulating" group: saline infusion produces a poor response on renin suppression, renal plasma flow and natriuresis; this inadequate response is corrected by ACE inhibitors.

The role of aldosterone in hypertension apart from the forms classically defined as primary hyperaldosteronism (PA) is supported by the majority of current studies indicating the increasing frequency of aldosterone excess either as PA or in the variant of moderate aldosterone excess. Excess aldosterone contributes significantly to the development and severity of hypertension, and also to resistance to antihypertensive treatment. Aldosterone itself or via complex interaction with ANG II contributes to increased BP, vascular aggression and cardiac fibrosis. Primary hyperaldosteronism is present in more than 
$15 \%$ of unselected cases of hypertension according to the new assessments (compared to the classic 1\%), and the proportion is even higher in cases of resistant hypertension. Studies of aldosteronism are not limited to patients defined as classic primary hyperaldosteronism and suggest that excess aldosterone is a more common cause of hypertension than plasma or urinary aldosterone measurements indicate ${ }^{(31,32)}$. The role of aldosterone in hypertension has been reassessed after it was found that about 50\% of patients with hypertension have alterations in aldosterone regulation, although most do not meet the diagnostic criteria for primary hyperaldosteronism (PA). In "essential" hypertension, BP levels often correlate with aldosterone levels (especially in obese people). Functional abnormalities of the adrenal cortex and adrenal steroids (urinary excretion, plasma level, clearance) have been demonstrated, and aldosterone level is predictive for the development of "essential" hypertension. The prospective analysis from a Framingham study indicates that basal aldosterone levels were associated with the development of hypertension over the next 4 years. The stimuli causing the increasing frequency of excessive aldosterone secretion are partially clarified. Studies highlight that obesity, excessive salt intake and genetic factors contribute to the increasing frequency of excess aldosterone ${ }^{(12,31,32)}$.

The term "aldosterone-related hypertension" refers to a group of patients classified as essential hypertension who have low plasma renin and an increased aldosterone/renin ratio (ARR) without a demonstrable diagnosis of PA. The group of hypertension with increased ARR represents a significant proportion of elderly hypertensive patients. Most people with excess aldosterone have bilateral adrenal hyperplasia which is a common post-mortem histological change in patients with hypertension and these patients develop hypertension with decreased renin and increased aldosterone/renin ratio (ARR).

It is now known that the increased ARR has a genetic substrate. Large population studies suggest that increased ARR is an inherited phenotype and that the risk of progression to hypertension is related to association with other gene variations or increased salt intake. In the long term, this association would be responsible for the genetic alteration of aldosterone secretion with the emergence of the phenotype of hypertension with increased ARR. In essential hypertension with increased ARR, 11- $\beta$-hydroxylase deficiency and its genetic substrate have been demonstrated as in PA.

Genetic studies indicate polymorphism of CYP11B2 and CYP11B1 genes, which encode aldosterone synthase and 11- $\beta$-hydroxylase, and association with hypertension with increased ARR; moreover, it has been hypothesized that $11-\beta$-hydroxylase deficiency, an abnormality with a genetic substrate, may be a common cause in PA and essential hypertension with increased ARR. In this case the conversion of deoxycortisol to cortisol is altered, with a moderate decrease in cortisol levels.

This results in a discrete but chronic increase in the ACTH-adrenal cortex axis, with bilateral adrenal cortical hyperplasia, with increased synthesis of cortisol and aldosterone. In these forms genetically determined increases in aldosterone secretion could lead during lifetime after many years to hypertension with volume expansion (reflected by low renin) and persistent increases in aldosterone in response to ANG II and potassium $^{(26,30)}$. Plasma aldosterone level and 


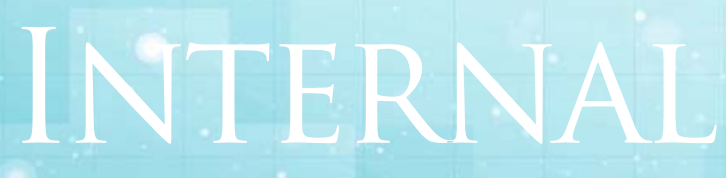

General Reviews

increased ARR ratio is predictive for the development and progression of reninindependent BP. Studies have shown that plasma aldosterone levels and abnormalities of 11- $\beta$-hydroxylase (encoded in the CYP11B1 gene) and aldosterone synthase (encoded in the CYP11B2 gene) in normotensive individuals correlated with subsequent elevation of BP and development of sustained hypertension ( $\mathrm{BP}>140 / 90 \mathrm{mmHg}$ ) or use of antihypertensive medication.

In these cases, biochemical abnormalities occur over time and are associated with increased and progressive hypertension. It is possible that, in predisposed individuals, variations in CYP11B2 may produce a degree of chronic activation of the hypothalamicpituitary-adrenal axis, with progressive increases in aldosterone production, renin suppression and hypertension with increased ARR. It can be anticipated that the increased ARR phenotype worsens over time in affected individuals and this pattern of development would explain the increased prevalence of low renin and diuretic-responsive hypertension in the elderly.

This hypothesis is based on a single type of genetic polymorphism. It is now accepted that essential hypertension is a polygenic condition in which other genes may also interact to lead to the phenotype of hypertension with increased ARR. On the other hand, people who do not have other gene variations favourable to hypertension and in the absence of dietary excess sodium would not develop particular abnormalities. A multitude of other genetic studies confirm the hormonal mechanisms in "essential" hypertension.

Gene polymorphisms in the renin gene (REN), $\beta$ 2-adrenergic receptor gene (ADR- $\beta$ 2) are currently known; both types are thought to correlate with salt-sensitive hypertension. Genic variations of ESR2 (estrogen receptor $\beta$ gene) are associated with cardiovascular disease (ESR2 is the gene for estrogen receptor ER- $\beta$ which is mainly expressed in the vascular system where it mediates the vasodilatory action of estrogen). Polymorphism of the ACE gene has been studied in relation to salt-sensitive hypertension. Genetic abnormalities of AGTR1 (angiotensin receptor type 1) are thought to correlate with vasoconstriction and hypertension, with no evidence of increased aldosterone secretion. However, current studies in humans are still inconsistent and have not clarified whether these gene variants mediate the pathophysiological mechanisms of hypertension and cardiovascular disease ${ }^{(25,27,30,34)}$.

The role of female and male sex hormones is known in regulating blood pressure. Their participation in the cellular and molecular mechanisms by which hormones can alter the effects of 
hypertension on the cardiovascular system has also been studied. Ovarian hormones may be partly responsible for reduced BP in pre-menopausal women and increased BP in post-menopausal women. Animal models show that BP is reduced after castration in males, but is not increased in females after oophorectomy. Studies indicate the action of endogenous estradiol in lowering BP in women; however, exogenous estrogenic preparations have an inconsistent effect on $\mathrm{BP}$, and the response to estrogenic treatment has been correlated with the type of estrogenic preparation and the dose of estrogen.

All studies show that estradiol is a vasodilator that reduces vascular resistance via multiple mechanisms: it increases NO production, increases the synthesis of other endogenous vasodilators, decreases the synthesis of endogenous vasoconstrictors and activates $\mathrm{K}^{+}$channels. In vivo studies also provide data on the effects of estradiol on the prevention of vascular remodelling and the influence of estradiol on the synthesis of factors associated with coagulation cascade and the fibrinolytic system. Unlike estradiol, testosterone is a pro-hypertensive hormone and contributes to BP elevation and the pathogenesis of cardiovascular disease by altering humoral factors including homocysteine, endothelin-1 and catecholamines $^{(35,36)}$.

All these data also explain the favourable effects of some antihypertensive drugs:

- ANG II blockers bring ANG II activity to a level appropriate to the fluid volume

- diuretics bring the fluid volume to a level appropriate to the ANG II level; they are less effective than ANG II blockers because volume contraction stimulates renin secretion, which in turn increases intrarenal and plasma ANG II levels
- aldosterone blockers

- $\beta$-blockers produce sympathetic inhibition, reduce cardiac output, inhibit renin secretion and thus ANG II production.

- New classes of pharmacological agents with multifunctional properties are being studied:

- new $\mathrm{AT}_{1}$ receptor blockers

- $\mathrm{AT}_{2}$ receptor agonists

- MAS receptor stimulating agents (ANG1-7 receptor, which antagonizes the effects of $A T_{1}$, with vasodilation and $B P$ lowering in experimental studies

- tissue ACE inhibitors produce favourable experimental effects in hypertension and coronary artery disease

- direct renin inhibitors, especially in combination with ACE or ARB achieve double blockade of RAAS and significantly reduce $B P$

- specific pro-renin receptor (PRR) blockers would reduce renin enzyme activity and prevent ANG-independent renin effects

- NEP inhibitors (neutral endopeptidase cleaves ANGI to ANG1-7)

- aldosterone synthase inhibitors have favourable experimental effects

- gene therapies are seen as a future solution for the management of hypertension.

Conventional antihypertensive therapies currently used include two, three or more hypertensive drugs, but most patients are not optimally controlled. Looking ahead, research on hypertension and cardiovascular disease aims to further investigate the aetiopathogenesis of the syndrome and to study new innovative strategies to lower cardiovascular risk. It is expected that experimental and clinical trials will demonstrate the favourable effects of the new therapeutic classes. 


\section{INTERNAL}

\section{General Reviews}

\section{Conclusions}

It can be concluded that studies over the last decade have reinforced the view that "essential" hypertension is a syndrome with multiple individual causes and a common clinical manifestation - high blood pressure. Today the differentiation between "secondary" and "essential" hypertension has become obscure, the classical division of hypertension into essential and secondary forms has become inconsistent, and the huge number of studies supports the multitude of mechanisms in "essential" hypertension.

Disorders of the RAS play an important role in the pathophysiology of hypertension, renal diseases and congestive heart failure. ANG II plays a main role in the initiation and amplification of pathophysiological mechanisms leading to vascular disease under conditions of dysregulation of RAS balance via genetic or environmental factors. The study of ANG II receptors and the mechanisms of action of ANG II, furthermore, shed light on the beneficial effects of angiotensin-converting enzyme inhibitors (ACE-I) and angiotensin receptor blockers (ARBs) with decreased morbidity and mortality in diabetes, hypertension, atherosclerosis, heart failure, stroke. RAS and aldosterone activation causes salt-sensitive hypertension, cardiovascular disease and chronic kidney disease. It is suggested that hypertension with low renin (and increased ARR) and idiopathic hyperaldosteronism may be variants of essential hypertension. It has been hypothesized that there is a link between the group of patients with increased $A R R$, the type of hypertension previously classified as low renin hypertension and nonmodulating patients.

Some authors consider that these phenotypes may be sequential steps in the natural history of hypertension in genetically predisposed individuals. In these forms of hypertension, genetically determined increases in aldosterone secretion could lead during lifetime after many years to hypertension with volume expansion (reflected by low renin) and persistent elevation of aldosterone. These groups of patients with hypertension would form a neurohormonal spectrum reflecting different stages of hypertension or even different stages of the natural history of hypertension in genetically susceptible individuals.

The renin-angiotensin-aldosterone axis has allowed species to survive and sustained life under reduced salt supply. In modern industrialised society the contribution of RAS and aldosterone to the regulation of homeostasis has fundamentally changed: the abundance of salt and the pandemic nature of obesity act synergistically to inappropriately activate the system. This vicious circle involving genetic and 
environmental lifestyle factors has led to the increasing prevalence of salt-sensitive hypertension and obesity-associated hypertension. These observations support the strategies needed to effectively reduce the incidence of hypertension: reducing salt intake in industrialised society and the wider use of aldosterone receptor blockers for the treatment of hypertension. It can be concluded that salt restriction is the most important strategy for the prevention of hypertension and hypertension-related cardiovascular injury.

\section{References}

1. Unger T. The role of the renin-angiotensin system in the development of cardiovascular disease. Am J Cardiol 89:3A-9A,2002.

2. Taniyama $Y$, Griendling $K K$. Reactive oxygen species in the vasculature: molecular and cellular mechanisms. Hypertension 42:1075-1081.2003.

3. Yan C, Kim D, Aizawa T, Berk BC. Functional interplay between angiotensin II and nitric oxide: cyclic GMP as a key mediator. Arterioscler Thromb Vasc Biol 23:26-36, 2003.

4. Carey RM. Update on the role of the AT2 receptor. Curr Opin Nephrol Hypertens 14:67-71,2005.

5. Ferrario CM, Trask AJ, Jessup JA. Advances in biochemical and functional roles of angiotensinconverting enzyme 2 and angiotensin-(1-7) in regulation of cardiovascular function. Am J Physiol Heart Circ Physiol 289:H2281-H2290,2005.

6. Grobe $J L$, Mecca AP, Lingis $M$, Shenoy $V$, Bolton TA, Machado JM, Speth RC, Raizada MK, Katovich MJ. Prevention of angiotensin llinduced cardiac remodeling by angiotensin-(1-7). Am J Physiol Heart Circ Physiol 292: H736-H742,2007.

7. Mehta PK, Griendling KK. Angiotensin II cell signaling: physiological and pathological effects in the cardiovascular system. Am J Physiol Cell Physiol 292:C82-C97,2007.

8. Katy Rivard, Scott A. Grandy, Annie Douillette, Pierre Paradis, MonaNemer, Bruce G. Allen, and Céline Fiset. Over expression of type 1 angiotensin II receptors impairs excitation-contraction coupling in themouse heart. AJP - Heart, vol. 301 no. 5 H2018-H2027, 2011.

9. Victor M Pulgar, Henry Yamashiro, James C Rose, Lorna G Moore. Role of the AT2 receptor in modulating the angiotensin II contractileresponse of the uterine artery at mid-gestation. Journal of Renin-Angiotensin-Aldosterone
System vol. 12 no. 3 176-183, 2011.

10. Danilczyk U, Penninger JM. Angiotensin-converting enzyme II in the heart and the kidney. Circ Res 98 463-471.2006.

11. Kaplan NM. Resistant hypertension. Journal of Hypertension. 23(8):1441-1444, 2005.

12. Bochud M, Nussberger J, Bovet P, Maillard MR, Elston $R C$, Paccaud F,et al. Plasma aldosterone is independently associated with the metabolic syndrome. Hypertension. 48:239-45.2006.

13. Giacchetti G, Ronconi V, Turchi F, Agostinelli L, Mantero F, Rilli S, et al. Aldosterone as a key mediator of the cardiometabolic syndrome in primary aldosteronism: an observational study. J Hypertens. 25:177-86.2007.

14. Caprio $M$, Fève $B$, Claës $A$, Viengchareun $S$, Lombès M, Zennaro MC. Pivotal role of the mineralocorticoid receptor in corticosteroid-induced adipogenesis. FASEB J. 21:218594.2007.

15. Guo C, Ricchiuti V, Lian BQ, Yao TM, Coutinho $P$, Romero JR, et al. Mineralocorticoid receptor blockade reverses obesity-related changes in expression of adiponectin, peroxisome proliferator-activated receptor gamma, and pro-inflammatory adipokines. Circulation. 117:2253-61.2008.

16. Lamounier-Zepter V, Ehrhart-Bornstein M. Fat tissue metabolism and adrenal steroid secretion. Curr Hypertens Rep.J 8:30-4.2006.

17. Fallo F, Della Mea P, Sonino N, Bertello C, Ermani M, Vettor $R$, et al.Adiponectin and insulin sensitivity in primary aldosteronism. Am J Hypertens. 20:855-61.2007.

18. Ferrario CM. Angiotensin-converting enzyme 2 and angiotensin-(1-7): an evolving story in cardiovascular regulation. Hypertension 47:515-521,2006.

19. Ferrario CM, Trask AJ, Jessup JA. Advances in biochemical and functional roles of angiotensinconverting enzyme 2 and angiotensin-(1-7) in regulation of cardiovascular function. Am J Physiol Heart Circ Physiol 289:H2281-H2290,2005.

20. Freele EM, Connel JM. Mechanisms of hypertension: the expanding role of aldosterone. J Am Soc Nephrol 15:1993-2001,2004.

21. Brown NJ. Aldosterone and vascular inflammation. Hypertension.51:161-7,2008.

22. Min LJ, Mogi M, Iwanami J, Li JM, Sakata A, Fujita T, et al. Cross-talk between aldosterone and angiotensin II in vascular smooth muscle cell senescence. Cardiovasc Res. 76:506-16.2007.

23. Carrie A. Northcott, Greg D. Fink, Hannah Garver, Joseph R. Haywood, Erinn L. Laimon-Thomson, Jonathon L. McClain, Paulo W. Pires, William E. Rainey, Christine S. Rigsby and Anne M. Dorrance, The Development of Hypertension and Hyperaldosteronism in a Rodent Model 
General Reviews

of Life-Long Obesity. Endocrinology, vol. 153 no. 4 17641773, 2012.

24. Ritz E. How Little Aldosterone is Able to Raise Blood Pressure? CJASN vol. 4 no. 4:703-710, 2009.

25. Catanzaro DF. Molecular biology of renin and regulation of its gene. In: Singh AK, Williams $G H$, eds. Textbook of Nephro-Endocrinology. San Diego, CA: Academic; 2017:389-400.91.

26. Carey MR, Padia SH. Physiology and regulation of the renin-angiotensin-aldosterone system. In: Singh $A K$, Williams GH, eds. Textbook of Nephro-Endocrinology, 2nd ed. San Diego, CA: Academic; 2017:1-23.276.

27. Kosachunhanun $N$, Hunt SC, Hopkins $P N$, Williams $R R$, Jeunemaitre $X$, Corvol $P$, Ferri $C$, Mortensen $R M$, Hollenberg NK, Williams GH. Genetic determinants of nonmodulating hypertension. Hypertension. 2003;4

28. Kolovou V, Lagou E, Mihas C, Vasiliki G, Katsiki N, Angiotensinogen (AGT) M235T, AGT T174M and angiotensin-1-converting enzyme (ACE) I/D gene polymorphisms in essential hypertension: effects on ramipril efficacy Open Cardiovasc MedJ. 2015;9(1):118-126.

29. Srivastava K, Chandra S, Bhatia J, Narang $R$, Saluja D. Association of angiotensinogen (M235T) gene polymorphism with blood pressure lowering response to angiotensin converting enzyme inhibitor (enalapril). J Pharm Pharm Sci. 2012;15(3):399-406.

30. Xi B, Shen Y, Reilly $K H$, Wang $X$, MiJ. Recapitulation of four hypertension susceptibility genes (CSK, CYP17A1, MTHFR, and FGF5) in East Asians. Metabolism 2013;62(2):196-203.

31. Calhoun DA. Aldosterone and cardiovascular disease: smoke and fire. Circulation. 14:2572-2574, 2006.

32. Lemarie CA, Paradis $P$, Schiffrin EL. New insights on signalling cascades induced by cross-talk between angiotensin II and aldosterone. J Mol Med. 86:673-678, 2008.

33. Goodfriend TL. Obesity, sleep apnea, aldosterone and hypertension. Current Hypertension Reports. 10(3):222-226, 2008.

34. Ramachandran V, Ismail P, Stanslas J, Shamsudin N. Analysis of renin-angiotensin aldosterone system gene polymorphisms in Malaysian essential hypertensive and type 2 diabetic subjects. Cardiovasc Diabetol. 2009;8(1):11.

35. Reckelhoff J.F, Gender differences in the regulation of blood pressure. Hypertension 2001;37:1199-1208.

36. ReckelhoffJ.F, Sex Steroids, Cardiovascular Disease and Hypertension: Unanswered Questions and Some speculations, Hypertension, 2005;45(2): 170-174. 